\title{
Image X-Ray Classification for COVID-19 Detection using GLCM-ELM
}

\author{
Vivin Umrotul M. Maksum ${ }^{1}$, Dian C. Rini Novitasari ${ }^{2 *}$, Abdulloh Hamid ${ }^{3}$ \\ ${ }^{1,2,3}$ Department of Mathematics, UIN Sunan Ampel Surabaya, Surabaya, Indonesia
}

\section{Article history:}

Received Feb 10, 2019

Revised May 21, 2021

Accepted Jun 3, 2021

Kata Kunci:

COVID-19, Citra X-

Ray, CAD, GLCM, ELM

Keywords:

COVID-19, X-Ray

image, CAD, GLCM, ELM

\begin{abstract}
Abstrak. COVID-19 merupakan penyakit atau virus yang baru-baru ini menyebar hampir di seluruh dunia. Penyakit ini juga telah memakan banyak korban karena virus ini terkenal mematikan. Pemeriksaan dapat dilakukan menggunakan chest X-Ray karena biaya yang dikeluarkan untuk chest X-Ray lebih murah dibandingkan dengan tes swab dan PCR. Pada penelitian ini data yang digunakan adalah data citra chest XRay. Citra chest X-Ray dapat diidentifikasi menggunakan ComputerAided Diagnosis System dengan memanfaatkan klasifikasi machine learning. Langkah awal yang dilakukan adalah tahap preprocessing, serta ekstraksi fitur menggunakan Gray Level Co-Occurrence Matrix (GLCM). Hasil dari proses ekstraksi fitur tersebut akan digunakan pada tahap klasifikasi. Proses klasifikasi yang digunakan adalah Extreme Learning Machine (ELM). Extreme Learning Machine (ELM) merupakan salah satu jaringan saraf tiruan dengan umpan maju (feedforward) yang mana memiliki satu lapisan tersembunyi yang disebut dengan Single Hidden Layer Feedforward Neural Networks (SLFNs). Pada penelitian ini hasil yang diperoleh dengan ekstraksi fitur GLCM dan klasifikasi menggunakan ELM menghasilkan akurasi terbaik sebesar $91.21 \%$, sensitifitas $100 \%$, dan spesifisitas $91 \%$ pada rotasi $135^{\circ}$ menggunakan fungsi aktivasi sin dengan percobaan node hidden 15 .
\end{abstract}

\begin{abstract}
COVID-19 is a disease or virus that has recently spread worldwide. The disease has also taken many casualties because the virus is notoriously deadly. An examination can be carried out using a chest X-Ray because it costs cheaper compared to swab and PCR tests. The data used in this study was chest X-Ray image data. Chest X-Ray images can be identified using Computer-Aided Diagnosis by utilizing machine learning classification. The first step was the preprocessing stage and feature extraction using the Gray Level Co-Occurrence Matrix (GLCM). The result of the feature extraction was then used at the classification stage. The classification process used was Extreme Learning Machine (ELM). Extreme Learning Machine (ELM) is one of the artificial neural networks with advanced feedforward which has one hidden layer called Single Hidden Layer Feedforward Neural Networks (SLFNs). The results obtained by GLCM feature extraction and classification using ELM achieved the best accuracy of $91.21 \%$, the sensitivity of $100 \%$, and the specificity of $91 \%$ at $135^{\circ}$ rotation using linear activation function with 15 hidden nodes.
\end{abstract}

How to cite:

V. U. M. Maksum, D. C. R. Novitasari, and A. Hamid, "Image X-Ray Classification for COVID19 Detection Using GCLM-ELM”, J. Mat. Mantik, vol. 7, no. 1, pp. 74-85, May 2021.

\section{CONTACT:}

Dian C. Rini Novitasari, $\boldsymbol{\nabla}$ diancrini@uinsby.ac.id Surabaya, Surabaya 60237, Indonesia 8 Department of Mathematics, UIN Sunan Ampel 



\section{Introduction}

The disease discussed by people around the world that was first discovered in Wuhan, Hubei Province, China which was reported to the World Health Organization (WHO) on December 31, 2019 is an outbreak of acute respiratory infection (pneumonia) caused by the new corona virus severe acute respiratory syndrome coronavirus 2 (SARS-CoV-2). On February 12, 2020, WHO officially declared the disease coronavirus disease 2019 (COVID-19). COVID-19 is an acute infectious disease that attacks the respiratory system [1-2]. The most common symptoms of patients infected with COVID-19 are fever, myalgia or fatigue, dry cough, headache, hemoptysis, diarrhea, and the patients slowly experience severe shortness of breath [3-4]. COVID-19 has a very fast growth rate but can be suppressed to balance medical care capabilities. Thus the death rate can be lowered [5].

Several ways have been carried out to reduce the increased rate of people with COVID19 diseases rapidly rising. One way is by swab or polymerase chain reaction (PCR) tests [6]. However, both of the tests require considerable time and cost. Therefore, the latest way to detect COVID-19 disease is by using X-Ray. X-Rays are considered capable of describing the condition of patients infected with COVID-19 and can also be a clinical diagnostic tool [7].

The first step in detecting COVID-19 based on X-Ray images is pre-processing image data [8]. In the pre-processing stage, feature extraction from X-Ray images is carried out using the Gray Level Co-occurrence Matrix (GLCM) method. GLCM is a second-order statistical method that calculates the relationship between two pixels in an image with degrees of grey. In previous research studies, GLCM has a good performance in extracting image features, and it was implemented to extract colposcopy image features before carrying out the classification process. The best accuracy results in the classification process are 95\%, which shows that the features extracted using the GLCM algorithm can represent images well [9]. The classification process can be done by several methods, one of which is the Extreme Learning Machine (ELM) method.

ELM is a feedforward neural network with a hidden layer with hidden node parameters randomly generated and the weights calculated analytically [10]. The classification using ELM has good performance with a relatively short computation time [11]. Based on previous research and the above explanation, this study classifies X-Ray images using the GLCM and ELM algorithms as feature extraction and classification to detect the presence of COVID-19. This research is expected to be implemented so that patients exposed to COVID-19 receive immediate and appropriate treatment.

\section{Preliminaries}

\subsection{Corona Virus Disease 2019 (COVID-19)}

Corona Virus Disease 2019 (COVID-19) is an infectious disease caused by a new virus and is known as severe acute respiratory syndrome coronavirus 2 (SARS-CoV-2) [12]. The disease attacks on the chest so it is almost similar to acute pneumonia [13]. The virus was first discovered in China on December 31, 2019 and on February 12, 2020, the World Health Organization (WHO) officially declared the disease COVID-19 [14].

COVID-19 is an animal-borne disease, but it can spread to humans. The most common symptoms of COVID-19 are fever, fatigue, and dry cough [15]. Some people may experience pain, nasal congestion, runny nose, headache, phlegm cough, sore throat, shortness of breath, and diarrhea [16]. These symptoms usually occur gradually, but some patients infected with COVID-19 do not show these symptoms and do not feel any problems with their bodies. People who are susceptible to COVID-19 are those who have a history of diseases related to the heart and blood vessels. COVID-19 cannot be seen only with the naked eye, but the disease can be seen using Chest X-Ray. Since COVID-19 
attacks the epithelial cells lining the respiratory tract, it can be analyzed using Chest X-Ray [17]. The following are the results of the COVID-19 Chest X-Ray, as shown in Figure 1.

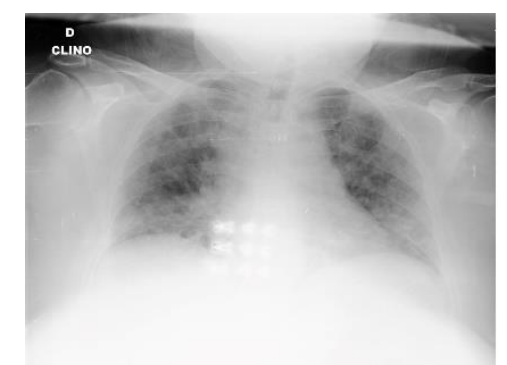

Figure 1. COVID-19 Chest X-Ray

\subsection{Gray Level Co-Occurrence Matrix (GLCM)}

Gray Level Co-occurrence Matrix (GLCM) is a very popular feature-based feature extraction method [18-19]. GLCM determines the texture relationship between pixels that have the same degree of grayness so that statistical features or features are obtained in an image [20]. GLCM is stored in the form of an $i \times j \times n$ matrix, where $\mathrm{n}$ is a GLCM number of different rotation directions [21]. The rotation direction is formed by four shifting directions of $0^{\circ}, 45^{\circ}, 90^{\circ}$ and $135^{\circ}$. There are several extraction features commonly used for GLCM extraction as shown from Equation(1) to Equation (4) [22] :

a. Contrast

Contrast is a variation of the local intensity value in the texture matrix. The lower texture contrast means the neighboring pixels on the matrix have similar local intensity values and vice versa. The following is an Equation to calculate the value of the contrast.

$$
\text { Contrast }=\sum_{a} \sum_{b} P_{a, b}(a-b)^{2}
$$

Where $P_{a, b}$ represents the pixel values in row a and column b in the co-currency matrix.

b. Homogeneity

Homogeneity is the degree of homogeneity of the repetition of textures.

$$
\text { Homogeneity }=\sum_{a} \sum_{b}\left(\frac{P_{a, b}}{1+(a-b)^{2}}\right)
$$

c. Energy

Energy is a measure of the uniformity of texture. The high value of energy represents a high degree of texture uniformity in an image. The following is an Equation to calculate the value of energy.

$$
\text { Energy }=\sum_{a} \sum_{b}\left(P_{a, b}\right)^{2}
$$

d. Correlation

Correlation is a measure of the degree of linear relationship of the grayness of one pixel relative to another.

$$
\text { Correlation }=\sum_{a} \sum_{b} P_{a, b} \frac{\left(a-\mu_{i}\right)\left(b-\mu_{j}\right)}{\sqrt{\sigma_{a}^{2} \sigma_{b}^{2}}}
$$

where,

$$
\begin{aligned}
\mu_{a} & : \sum_{a} \sum_{b} a \cdot P_{a, b} \\
\mu_{b} & : \sum_{a} \sum_{b} b \cdot P_{a, b} \\
\sigma_{a} & : \sqrt{\sum_{a} \sum_{b}\left(a-\mu_{a}\right)^{2} P_{a, b}} \\
\sigma_{b} & : \sqrt{\sum_{a} \sum_{b}\left(b-\mu_{b}\right)^{2} P_{a, b}}
\end{aligned}
$$




\subsection{K-Fold Cross Validation}

K-fold cross validation or also called rotation estimation is a technique to minimize bias by random sampling of training and testing data [23]. One technique of k-fold cross validation is to estimate how accurate a model is when executed. In addition, the technique of $\mathrm{k}$-fold cross validation breaks the data into $\mathrm{K}$ parts of the same size. Training and testing are conducted as many times as $\mathrm{K}$ times. The first experiment is a subset of D1 data into testing data and the other subset of data into training data, the second experiment is a subset of $\mathrm{D}_{2}$ data into testing data and a subset of $D_{1}, D_{3}$ data up to a subset of $D_{k}$ data into training data [24]. The illustration of the k-fold cross validation is shown in Figure 2

Data Partition and Validation Iteration for $\mathrm{k}=4$

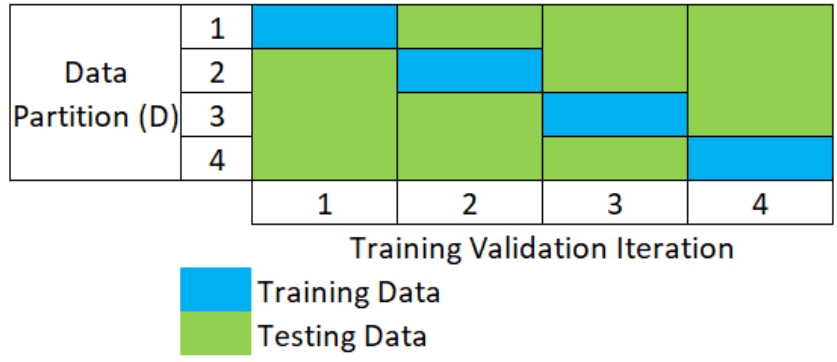

Figure 2. Data partition using K-Fold Cross Validation

\subsection{Extreme Learning Machine (ELM)}

Extreme Learning Machine (ELM) is a feedforward neural network with one hidden layer or commonly referred to as Single Hidden Layer Feedforward Neural Networks (SLFNs) [25].

In ELM algorithms, hidden node learning parameters including weight input and bias input can be randomly assigned. For network output weights can be determined analytically using simple general inverse operations [26]. The advantage of using ELM is efficient training without time-consuming learning for the process. In addition, on a universal approach, ELM capabilities have been successfully applied in many real-world applications, such as classification and regression issues [11].

ELM has a mathematical model that differs from backpropagation with a simpler and more effective model [27]. ELM neural network model with neuron inputs, hidden layer neurons, and activation function $g(x)$. Purpose $n=$ $\left[x_{1}, x_{2}, x_{3}, \cdots, x_{n}\right]$ with $x_{n}$ is the input value on the network, $H$ is a matrix connecting the input layer and hidden layer, then the matrix has a size $n \times m$. The determination of the values of the matrix elements is done randomly which can be formulated as follows [11]:

where,

$$
\sum_{i=1}^{m} \beta_{i} g\left(w_{i} x_{j}+b_{j}\right)=Y
$$

$Y$ : predicted data,

$\beta_{i}$ : weight that connect hidden nodes and output nodes with $\beta_{i}=\left(\beta_{1}, \beta_{2}, \cdots, \beta_{m}\right)$,

$w_{i}$ : the weight that connects the hidden node to the $\mathrm{i}$ and the input nodes with $w_{i}=\left(w_{1 i}, w_{2 i}, \cdots, w_{p i}\right)$

$x_{j} \quad$ : vector input data with $x_{j}=x_{j(t-1)}, x_{j(t-2)}, \cdots, x_{j(t-p)}$

$j \quad$ : numbers $1,2, \cdots, m$ 
$b_{i} \quad$ : bias weight to the i hidden node with $b_{i}=\left(b_{1}, b_{2}, \cdots, b_{m}\right)$

Equation (5) can be converted into a matrix as Equation (6)

$$
H \beta=Y
$$

where,

$H=\left[\begin{array}{ccc}g\left(w_{1} x_{1}+b_{1}\right) & \cdots & g\left(w_{m} x_{1}+b_{m}\right) \\ \vdots & \ddots & \vdots \\ g\left(w_{n} x_{n, 1}+b_{n}\right) & \cdots & g\left(w_{m, n} x_{n}+b_{m}\right)\end{array}\right]$, dan $\beta=\left[\begin{array}{c}\beta_{1} \\ \vdots \\ \beta_{m}\end{array}\right]$

$\beta$ the matrix of the output weights and T is the matrix of the target. In ELM, weights and bias values are determined randomly. So that the output weight associated with the hidden layer can be determined by Equation [28]:

$$
\beta=H^{+} Y
$$

Where $\mathrm{H}^{+}$is a matrix that uses Moore Penrose Pseudo Inverse theory which has the best generalization results with fast computation time. In the ELM architecture described above, each node on the input is connected to a node in the hidden layer using the activation function $g\left(w_{m} x_{n}+b_{m}\right)$ thus resulting in an $\mathrm{H}$ matrix of many nodes $\times$ lots of data [29].

\subsection{Confusion Matrix}

Confusion matrix with a size of $2 \times 2$ associated with the classifier shows the results of classification and actual data where TP (True Positive) is a class which is actually positive and predicted positive, so class labels are predicted correctly. And TN (True Negative) is a class of actually negative and predicted negative, so class labels are predicted correctly. Whereas, FP (False Positive) is a class of actually negative but predicted positive, so class labels are predicted wrong, and FN (False Negative) is a class of actually positive but predicted negative, so class labels are predicted wrong [30]. This can be seen in Table 1 as follows:

Table 1. Confusion Matrix

\begin{tabular}{ccc}
\hline \multirow{2}{*}{ Predicted Value } & \multicolumn{2}{c}{ Actual Value } \\
\cline { 2 - 3 } True & True & False \\
False & True Positive (TP) & False Positive (FP) \\
\hline \hline
\end{tabular}

From Table 2.1, the level of accuracy, sensitivity, and specificity of an algorithm model can be calculated using Equation 8, 9, and 10 [18] .

$$
\begin{aligned}
& \text { Accuracy }=\frac{T P+T N}{T P+T N+F P+F N} \times 100 \\
& \text { Sensitivity }=\frac{T P}{T P+F N} \times 100 \\
& \text { Specificity }=\frac{T N}{T N+F P} \times 100
\end{aligned}
$$

\section{Research Method}

\subsection{Data}

This study used chest X-Ray image data consisting of 1031 data derived from [31]. Table 2 shows the data used in this study. 
Vivin Umrotul M. Maksum, Dian C. Rini Novitasari, Abdulloh Hamid

Image X-Ray Classification for COVID-19 Detection Using GCLM-ELM

Table 2. Research Data Details

\begin{tabular}{ccc}
\hline Data Type & Data Format & Number of Data \\
\hline COVID-19 & JPEG & 119 \\
Non COVID-19 & JPEG & 912 \\
\hline
\end{tabular}

The data was taken on 03 April 2020 from [32-35]. The data increased every week so that when retrieving at different times the number of data increased.

\subsection{Research Type}

This type of research is applied research. In this research report, a system is created to check whether a person is suffering from COVID-19 by using ELM method. Figure 3 is the flowchart for the detection of COVID-19.

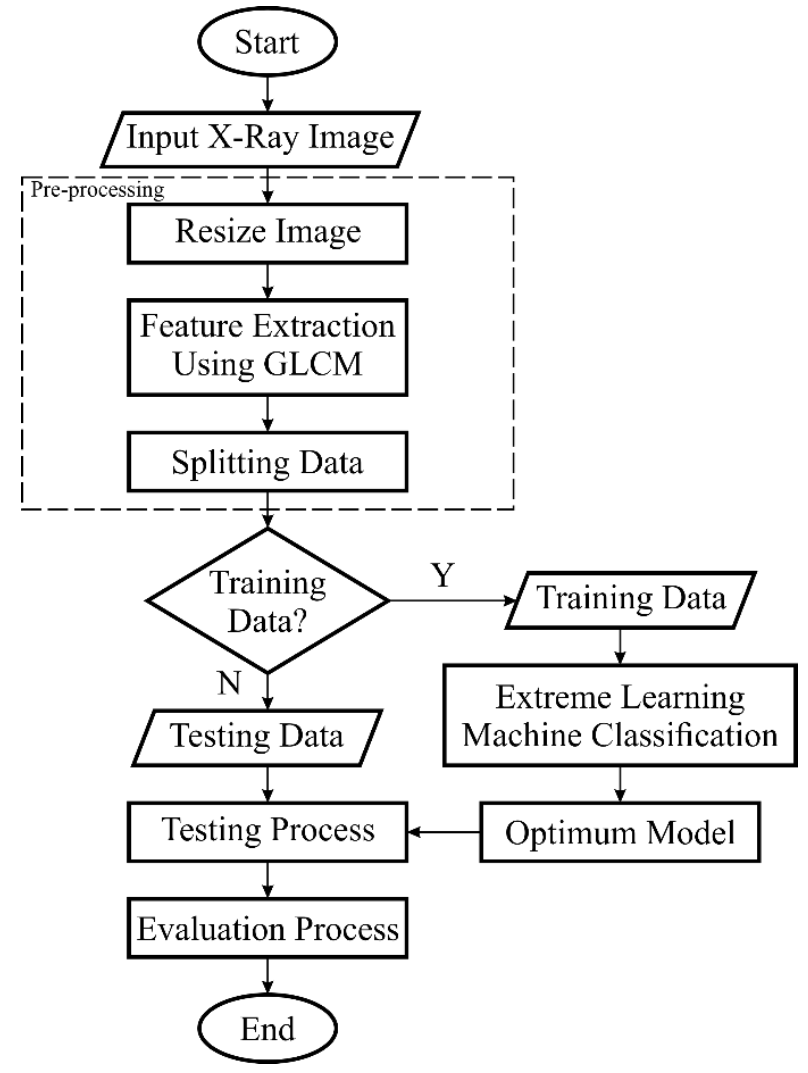

Figure 3. COVID-19 Detection using GLCM-ELM Flowchart

\section{Results and Discussion}

Experiments of $\mathrm{k}=5$ were conducted in this study using hidden nodes of $5,10,15$, $20,25,30$ and 35 , then experiments were al so conducted using several activation functions, that is sigmoid activation function, linear, sin, and radial basis. The results on the experiments using the hidden nodes of 5, 10, 15, 20, 25, 30 and 35, as well as those of the activation functions consisting of sigmoid, linear, sin and radial basis using four rotation directions of $0^{\circ}, 45^{\circ}, 90^{\circ}$ and $135^{\circ}$ are shown in the following table 3 , table 4 , table 5 and table 6 . 
Table 3. COVID-19 and Non COVID-19 Classification using GLCM-ELM with $0^{\circ}$ Direction

\begin{tabular}{|c|c|c|c|c|}
\hline Hidden Nodes & $\begin{array}{l}\text { Activation } \\
\text { Function }\end{array}$ & Accuracy & Sensitivity & Specificity \\
\hline \multirow{4}{*}{5} & Sigmoid & 88.35 & 50.00 & 89.10 \\
\hline & Linear & 88.83 & 100.00 & 88.78 \\
\hline & Sin & 88.83 & 66.67 & 89.16 \\
\hline & Radial Basis & 87.86 & 33.33 & 88.67 \\
\hline \multirow{4}{*}{10} & Sigmoid & 88.84 & 50.00 & 89.60 \\
\hline & Linear & 87.86 & 100.00 & 88.72 \\
\hline & Sin & 88.34 & 40.00 & 89.55 \\
\hline & Radial Basis & 88.83 & 50.00 & 90.00 \\
\hline \multirow{4}{*}{15} & Sigmoid & 91.26 & 85.71 & 91.46 \\
\hline & Linear & 88.83 & 50.00 & 89.22 \\
\hline & Sin & 89.86 & 71.42 & 90.5 \\
\hline & Radial Basis & 89.37 & 75.00 & 89.66 \\
\hline \multirow{4}{*}{20} & Sigmoid & 91.26 & 80.00 & 91.83 \\
\hline & Linear & 88.83 & 100.00 & 88.78 \\
\hline & Sin & 90.29 & 75.00 & 90.90 \\
\hline & Radial Basis & 89.80 & 66.67 & 90.86 \\
\hline \multirow{4}{*}{25} & Sigmoid & 88.84 & 54.55 & 90.77 \\
\hline & Linear & 88.84 & 100.00 & 88.78 \\
\hline & Sin & 87.86 & 42.86 & 89.45 \\
\hline & Radial Basis & 87.86 & 44.44 & 89.85 \\
\hline \multirow{4}{*}{30} & Sigmoid & 91.26 & 77.78 & 91.88 \\
\hline & Linear & 88.84 & 66.67 & 89.16 \\
\hline & Sin & 91.75 & 73.33 & 93.19 \\
\hline & Radial Basis & 90.29 & 64.28 & 92.19 \\
\hline \multirow{4}{*}{35} & Sigmoid & 91.75 & 81.82 & 92.31 \\
\hline & Linear & 88.44 & 50.00 & 88.72 \\
\hline & Sin & 89.81 & 58.82 & 92.59 \\
\hline & Radial Basis & 88.35 & 50.00 & 91.15 \\
\hline
\end{tabular}

Table 4. COVID-19 and Non COVID-19 Classification Results using GLCM-ELM with 45 Direction

\begin{tabular}{ccccc}
\hline Hidden Nodes & $\begin{array}{c}\text { Activation } \\
\text { Function }\end{array}$ & Accuracy & Sensitivity & Specificity \\
\hline \multirow{2}{*}{5} & Sigmoid & 89.32 & 100.00 & 89.21 \\
& Linear & 89.32 & 75.00 & 89.6 \\
& Sin & 88.84 & 66.67 & 89.16 \\
& Radial Basis & 88.83 & 100.00 & 88.78 \\
10 & Sigmoid & 87.37 & 34.00 & 89.00 \\
& Linear & 88.35 & 50.00 & 89.10 \\
& Sin & 87.86 & 43.00 & 89.45 \\
& Radial Basis & 87.37 & 34.00 & 89.00 \\
& Sigmoid & 90.34 & 75.00 & 90.95 \\
& Linear & 88.40 & 50.00 & 88.78 \\
& Sin & 90.82 & 77.78 & 91.41 \\
& Radial Basis & 91.30 & 80.00 & 91.87 \\
& Sigmoid & 92.72 & 83.33 & 93.30 \\
& Linear & 89.81 & 100.00 & 89.71 \\
& Sin & 92.23 & 76.92 & 93.23 \\
& Radial Basis & 91.75 & 80.00 & 92.35 \\
& Sigmoid & 90.82 & 66.67 & 92.70 \\
& Linear & 89.37 & 100.00 & 89.27 \\
& Sin & 92.27 & 75.00 & 93.72 \\
& Radial Basis & 91.30 & 71.43 & 92.75 \\
\hline
\end{tabular}


Vivin Umrotul M. Maksum, Dian C. Rini Novitasari, Abdulloh Hamid Image X-Ray Classification for COVID-19 Detection Using GCLM-ELM

Table 4. COVID-19 and Non COVID-19 Classification Results using GLCM-ELM with 45 Direction (continued)

\begin{tabular}{ccccc}
\hline Hidden Nodes & $\begin{array}{c}\text { Activation } \\
\text { Function }\end{array}$ & Accuracy & Sensitivity & Specificity \\
\hline \multirow{3}{*}{30} & Sigmoid & 90.78 & 72.72 & 91.79 \\
& Linear & 89.32 & 100.00 & 89.22 \\
& Sin & 90.78 & 72.73 & 91.79 \\
& Radial Basis & 90.29 & 70.00 & 91.32 \\
35 & Sigmoid & 90.78 & 72.73 & 91.80 \\
& Linear & 89.32 & 100.00 & 89.22 \\
& Sin & 90.78 & 72.73 & 91.79 \\
& Radial Basis & 90.29 & 70.00 & 91.33 \\
\hline
\end{tabular}

Table 5. COVID-19 and Non COVID-19 Classification Results using GLCM-ELM 90 Direction

\begin{tabular}{|c|c|c|c|c|}
\hline Hidden Nodes & $\begin{array}{l}\text { Activation } \\
\text { Function }\end{array}$ & Accuracy & Sensitivity & Specificity \\
\hline \multirow{4}{*}{5} & Sigmoid & 89.80 & 100.00 & 89.65 \\
\hline & Linear & 89.32 & 75.00 & 89.60 \\
\hline & $\operatorname{Sin}$ & 88.40 & 50.00 & 88.78 \\
\hline & Radial Basis & 90.24 & 100.00 & 90.00 \\
\hline \multirow{4}{*}{10} & Sigmoid & 89.32 & 66.67 & 90.00 \\
\hline & Linear & 90.29 & 100.00 & 90.00 \\
\hline & $\operatorname{Sin}$ & 90.29 & 75.00 & 90.90 \\
\hline & Radial Basis & 88.40 & 50.00 & 88.78 \\
\hline \multirow{4}{*}{15} & Sigmoid & 91.75 & 88.9 & 91.88 \\
\hline & Linear & 89.32 & 100.00 & 89.21 \\
\hline & $\operatorname{Sin}$ & 90.29 & 83.40 & 90.50 \\
\hline & Radial Basis & 90.30 & 75.00 & 90.90 \\
\hline \multirow{4}{*}{20} & Sigmoid & 89.81 & 80.00 & 90.04 \\
\hline & Linear & 89.32 & 100.00 & 89.22 \\
\hline & $\operatorname{Sin}$ & 89.81 & 80.00 & 90.04 \\
\hline & Radial Basis & 89.81 & 80.00 & 90.04 \\
\hline \multirow{4}{*}{25} & Sigmoid & 89.80 & 63.64 & 91.28 \\
\hline & Linear & 88.84 & 100.00 & 88.78 \\
\hline & $\operatorname{Sin}$ & 89.32 & 58.33 & 91.24 \\
\hline & Radial Basis & 89.32 & 62.50 & 90.90 \\
\hline \multirow{4}{*}{30} & Sigmoid & 88.84 & 54.55 & 90.78 \\
\hline & Linear & 88.35 & 50.00 & 88.73 \\
\hline & $\operatorname{Sin}$ & 88.84 & 55.56 & 90.36 \\
\hline & Radial Basis & 88.84 & 54.55 & 90.77 \\
\hline \multirow{4}{*}{35} & Sigmoid & 92.72 & 80.00 & 93.72 \\
\hline & Linear & 88.84 & 66.68 & 89.16 \\
\hline & $\operatorname{Sin}$ & 93.20 & 85.71 & 93.75 \\
\hline & Radial Basis & 92.72 & 80.00 & 93.72 \\
\hline
\end{tabular}


Table 6. COVID-19 and Non COVID-19 Classification Results using GLCM-ELM with $135^{\circ}$ Direction

\begin{tabular}{|c|c|c|c|c|}
\hline Hidden Nodes & $\begin{array}{l}\text { Activation } \\
\text { Function }\end{array}$ & Accuracy & Sensitivity & Specificity \\
\hline \multirow{4}{*}{5} & Sigmoid & 88.89 & 100.00 & 88.84 \\
\hline & Linear & 89.37 & 100.00 & 89.27 \\
\hline & Sin & 88.83 & 100.00 & 88.89 \\
\hline & Radial Basis & 89.32 & 75.00 & 89.60 \\
\hline \multirow{4}{*}{10} & Sigmoid & 88.83 & 57.14 & 89.95 \\
\hline & Linear & 88.35 & 50.00 & 89.10 \\
\hline & Sin & 89.32 & 100.00 & 89.21 \\
\hline & Radial Basis & 89.80 & 100.00 & 89.65 \\
\hline \multirow{4}{*}{15} & Sigmoid & 90.73 & 100.00 & 90.54 \\
\hline & Linear & 89.75 & 100.00 & 89.66 \\
\hline & Sin & 91.21 & 100.00 & 91.00 \\
\hline & Radial Basis & 89.80 & 66.67 & 90.86 \\
\hline \multirow{4}{*}{20} & Sigmoid & 92.23 & 81.82 & 92.82 \\
\hline & Linear & 89.32 & 100.00 & 89.27 \\
\hline & Sin & 92.23 & 81.82 & 92.82 \\
\hline & Radial Basis & 90.78 & 70.00 & 91.84 \\
\hline \multirow{4}{*}{25} & Sigmoid & 89.86 & 58.82 & 92.63 \\
\hline & Linear & 88.89 & 60.00 & 89.60 \\
\hline & $\operatorname{Sin}$ & 91.30 & 71.43 & 92.75 \\
\hline & Radial Basis & 90.82 & 64.71 & 93.16 \\
\hline \multirow{4}{*}{30} & Sigmoid & 90.29 & 62.50 & 92.63 \\
\hline & Linear & 87.38 & 33.33 & 89.00 \\
\hline & Sin & 90.78 & 66.67 & 92.67 \\
\hline & Radial Basis & 91.75 & 76.92 & 92.75 \\
\hline \multirow{4}{*}{35} & Sigmoid & 90.78 & 77.78 & 91.37 \\
\hline & Linear & 89.32 & 100.00 & 89.22 \\
\hline & Sin & 90.78 & 77.78 & 91.37 \\
\hline & Radial Basis & 90.78 & 77.78 & 91.37 \\
\hline
\end{tabular}

The best results are seen from the values of sensitivity, accuracy, and specificity. In this COVID-19 detection system, the best sensitivity value is to avoid misdiagnosis that patients with COVID-19 disease are detected incorrectly as Non COVID-19. Table 3 represents the test results at $0^{\circ}$, using the linear activation function and 25 hidden nodes, and give the sensitivity, accuracy, and specificity values are $100 \%, 88.84 \%$, and $88.78 \%$, respectively. Table 4 represents the test results at $45^{\circ}$, using the linear activation function and 20 hidden nodes, and give sensitivity, accuracy, and specificity values are $100 \%$, $89.81 \%$, and $89.71 \%$, respectively. GLCM feature extraction with an angle of $90^{\circ}$ using linear activation function and 10 hidden nodes obtained sensitivity, accuracy, and specificity values of $100 \%, 90.29 \%$, and $90 \%$. Meanwhile, in Table 6, the feature extraction at an angle of $135^{\circ}$ with 15 hidden nodes and the activation function sin obtained the best sensitivity, accuracy, and specificity results of $100 \%, 91.21 \%$, and $91 \%$.

The best results from each trial, based on the feature extraction direction, were obtained using the activation function parameters sin, 10 hidden nodes, and the feature extraction direction of $135^{\circ}$, namely with sensitivity, accuracy, and specificity values of $100 \%, 91.21 \%$, and $91 \%$. Future research is expected to increase the sensitivity and accuracy with other feature extraction methods such as Gray Level Run-Length Matrix (GLRLM). In a study conducted by [34], GLRLM had better accuracy quality than the GLCM method. The future work is by applying ELM development methods, namely the Kernel Extreme Learning Machine (K-ELM) [35] and Multi-Layer Extreme Learning Machine (MLLEM) [36]. 


\section{Conclusions}

The feature extraction process using GLCM method can analyze the images of COVID-19 and Non COVID-19. Based on the extraction results of the GLCM feature with the four features used, it is shown that the extracted images produced good value. Good sensitivity was achieved from the feature extraction with $90^{\circ}$.

Covid-19 classification using Extreme Learning Machine (ELM) method shows good results. The classification of COVID-19 in this study is divided into two classes, namely COVID-19 and Non COVID-19 which produced the best results at the rotation of $135^{\circ}$ with the accuracy of $91.21 \%$, the sensitivity of $100 \%$, and the specificity of $91 \%$ on hidden nodes 15 using the activation function of sin.

\section{References}

[1] Z. Y. Zu et al., "Coronavirus disease 2019 (COVID-19): a perspective from China," Radiology, vol. 296, no. 2, pp. E15-E25, 2020.

[2] P. Boldog, T. Tekeli, Z. Vizi, A. Dénes, F. A. Bartha, and G. Röst, "Risk assessment of novel coronavirus COVID-19 outbreaks outside China," J. Clin. Med., vol. 9, no. 2, p. $571,2020$.

[3] K.-C. Liu et al., "CT manifestations of coronavirus disease-2019: a retrospective analysis of 73 cases by disease severity," Eur. J. Radiol., vol. 126, p. 108941, 2020.

[4] C. Huang et al., "Clinical Features of Patients Infected with 2019 Novel Coronavirus in Wuhan, China," pp. 497-506, 2020.

[5] D. Wang et al., "Clinical characteristics of 138 hospitalized patients with 2019 novel coronavirus-infected pneumonia in Wuhan, China," Jama, vol. 323, no. 11, pp. 1061-1069, 2020.

[6] J. E. Corral et al., "COVID-19 polymerase chain reaction testing before endoscopy: an economic analysis," Gastrointest. Endosc., vol. 92, no. 3, pp. 524-534, 2020.

[7] D. C. R. Novitasari et al., "Detection of covid-19 chest x-ray using support vector machine and convolutional neural network," Commun. Math. Biol. Neurosci., vol. 2020, p. Article-ID, 2020.

[8] A. H. Asyhar, A. Z. Foeady, M. Thohir, A. Z. Arifin, D. Z. Haq, and D. C. R. Novitasari, "Implementation LSTM Algorithm for Cervical Cancer using Colposcopy Data," 2020 Int. Conf. Artif. Intell. Inf. Commun., pp. 485-489, 2020.

[9] M. Thohir, A. Z. Foeady, D. C. R. Novitasari, A. Z. Arifin, B. Y. Phiadelvira, and A. H. Asyhar, "Classification of Colposcopy Data Using GLCM-SVM on Cervical Cancer," in 2020 International Conference on Artificial Intelligence in Information and Communication (ICAIIC), 2020, pp. 373-378.

[10] Y. Wang, Z. Li, L. Feng, C. Zheng, and W. Zhang, "Automatic detection of epilepsy and seizure using multiclass sparse extreme learning machine classification," Comput. Math. Methods Med., vol. 2017, 2017.

[11] S. Ding, H. Zhao, Y. Zhang, X. Xu, and R. Nie, "Extreme learning machine: algorithm, theory and applications," Artif. Intell. Rev., vol. 44, no. 1, pp. 103-115, 2015.

[12] B. S. Chhikara, B. Rathi, J. Singh, and F. N. U. Poonam, "Corona virus SARS-CoV2 disease COVID-19: Infection, prevention and clinical advances of the prospective chemical drug therapeutics," Chem. Biol. Lett., vol. 7, no. 1, pp. 63-72, 2020. 
[13] L. Lin, L. Lu, W. Cao, and T. Li, "Hypothesis for potential pathogenesis of SARSCoV-2 infection-a review of immune changes in patients with viral pneumonia," Emerg. Microbes Infect., vol. 9, no. 1, pp. 727-732, 2020.

[14] Y. Jee, "WHO international health regulations emergency committee for the COVID-19 outbreak," Epidemiol. Health, vol. 42, 2020.

[15] H. Al-Najjar and N. AL-Rousan, "Can Covid-19 Virus be created in the Laboratory?: A Theoretical Experimental Study," A Theor. Exp. Study (April 22, 2020), 2020.

[16] W. Ji, G. Bishnu, Z. Cai, and X. Shen, "Analysis clinical features of COVID-19 infection in secondary epidemic area and report potential biomarkers in evaluation," MedRxiv, 2020.

[17] H. Dai et al., "High-resolution chest CT features and clinical characteristics of patients infected with COVID-19 in Jiangsu, China," Int. J. Infect. Dis., vol. 95, pp. 106-112, 2020.

[18] A. Z. Foeady, D. C. R. Novitasari, A. H. Asyhar, and M. Firmansjah, "Automated Diagnosis System of Diabetic Retinopathy Using GLCM Method and SVM Classifier," Proceeding Electr. Eng. Comput. Sci. Informatics, vol. 5, no. 1, pp. 154160, 2018.

[19] D. C. R. Novitasari, W. T. Puspitasari, P. Wulandari, A. Z. Foeady, and M. F. Rozi, "Klasifikasi Alzheimer dan Non Alzheimer Menggunakan Fuzzy C-Mean, Gray Level Co-Occurence Matrix dan Support Vector Machine," J. Mat. MANTIK, vol. 4, no. 2, pp. 83-89, 2018.

[20] Ş. Öztürk and B. Akdemir, "Application of feature extraction and classification methods for histopathological image using GLCM, LBP, LBGLCM, GLRLM and SFTA," Procedia Comput. Sci., vol. 132, pp. 40-46, 2018.

[21] A. Harshavardhan, S. Babu, and T. Venugopal, "Analysis of feature extraction methods for the classification of brain tumor detection," Int. J. Pure Appl. Math., vol. 117, no. 7, pp. 147-155, 2017.

[22] M. Hall-Beyer, "Practical guidelines for choosing GLCM textures to use in landscape classification tasks over a range of moderate spatial scales," Int. J. Remote Sens., vol. 38, no. 5, pp. 1312-1338, 2017.

[23] B. Ghojogh and M. Crowley, "The theory behind overfitting, cross validation, regularization, bagging, and boosting: tutorial," arXiv Prepr. arXiv1905.12787, 2019.

[24] T.-T. Wong and N.-Y. Yang, "Dependency analysis of accuracy estimates in k-fold cross validation," IEEE Trans. Knowl. Data Eng., vol. 29, no. 11, pp. 2417-2427, 2017.

[25] M. A. A. Albadra and S. Tiuna, "Extreme learning machine: a review," Int. J. Appl. Eng. Res., vol. 12, no. 14, pp. 4610-4623, 2017.

[26] F. Kang, J. Liu, J. Li, and S. Li, "Concrete dam deformation prediction model for health monitoring based on extreme learning machine," Struct. Control Heal. Monit., vol. 24, no. 10, p. e1997, 2017.

[27] Y. Kuang, Q. Wu, J. Shao, J. Wu, and X. Wu, "Extreme learning machine classification method for lower limb movement recognition," Cluster Comput., vol. 20, no. 4, pp. 3051-3059, 2017.

[28] S. Handika, I. Gririantari, and A. Dharma, "Perbandingan Metode Extreme Learning Machine dan Particle Swarm Optimization Extreme Learning Machine untuk 
Peramalan Jumlah Penjualan Barang," Maj. Ilm. Teknol. Elektro, vol. 15, no. 1, p. 84, 2016.

[29] J. Cao, K. Zhang, M. Luo, C. Yin, and X. Lai, "Extreme learning machine and adaptive sparse representation for image classification," Neural networks, vol. 81, pp. 91-102, 2016.

[30] X. Deng, Q. Liu, Y. Deng, and S. Mahadevan, "An improved method to construct basic probability assignment based on the confusion matrix for classification problem," Inf. Sci. (Ny)., vol. 340-341, pp. 250-261, 2016.

[31] D. S. Kermany et al., "Identifying medical diagnoses and treatable diseases by image-based deep learning," Cell, vol. 172, no. 5, pp. 1122-1131, 2018.

[32] P. Mooney, "Chest X-Ray Images (Pneumonia)," Kaggle, 2018. .

[33] Github, "Covid Chest X-Ray Dataset," 2019. .

[34] D. C. R. Novitasari, A. Lubab, A. Sawiji, and A. H. Asyhar, "Application of feature extraction for breast cancer using one order statistic, GLCM, GLRLM, and GLDM," Adv. Sci. Technol. Eng. Syst. J., vol. 4, no. 4, pp. 115-120, 2019.

[35] D. C. R. Novitasari, A. H. Asyhar, M. Thohir, A. Z. Arifin, H. Mu'jizah, and A. Z. Foeady, "Cervical Cancer Identification Based Texture Analysis Using GLCMKELM on Colposcopy Data," in 2020 International Conference on Artificial Intelligence in Information and Communication (ICAIIC), 2020, pp. 409-414.

[36] S. Ding, N. Zhang, X. Xu, L. Guo, and J. Zhang, "Deep Extreme Learning Machine and Its Application in EEG Classification," Math. Probl. Eng., vol. 2015, 2015. 